\title{
Relevansi Pemikiran Pendidikan Abdurrahman Wahid dan Abdurrahman An-Nahlawi di Era Modern
}

\section{Siti Kasanah}

Fakultas Ilmu Tarbiyah dan Keguruan, UIN Sunan Kalijaga Yogyakarta, Indonesia kasanahsiti47@gmail.com

\begin{abstract}
Tthe aim this study is] to find out the appropriateness of educational thinking according to Abdurrahman Wahid and Abdurrahman An-Nahlawi to education now. The method used is study research use books and other literat ure to the first resources. Technique data of analysis is analysis information have go and compare information to get conclusion. The results of this study show that the concept of education based on the thoughts of Abdurrahman Wahid and An-Nahlawi is still very Because the learning doesn't only teach common knowledge, but also religion knowledge, exactly Islam, where this education is really needed nowdays for making students' attitude better
\end{abstract}

Keywords: Abdurrahman Wahid's thoughts, Abdurrahman An-Nahlawi, educational thoughts

\begin{abstract}
Abstrak
Penelitian ini bertujuan untuk mengetahui relevansi pemikiran pendidikan menurut Abdurrahman Wahid dan Abdurrahman An-Nahlawi terhadap pendidikan saat ini. Metode yang digunakan dalam penelitian ini adalah study research yang menggunakan buku-buku dan literatur-literatur lainnya sebagai sumber data yang utama. Teknik analisis data menggunakan content analysis yaitu menganalisis informasi yang didapatkan dengan cara membandingkan informasi tersebut untuk ditarik kesimpulan. Hasil penelitian ini menujukkan bahwa konsep pendidikan berdasarkan pemikiran Abdurrahman Wahid dan AnNahlawi masih sangat relevan karena pembelajarannya tidak hanya mengajarkan pengetahuan umum tetapi juga pengetahuan agama khususnya agama Islam, dimana pendidikan tersebut sangat dibutuhkan pada era saat ini untuk memperbaiki akhlak peserta didik].
\end{abstract}

Kata Kunci: Abdurrahman Wahid, Abdurrahman An-Nahlawi, pemikiran pendidikan

\section{Pendahuluan}

Era globalisasi merupakan tatanan masyarakat yang mendunia yang tidak bisa dihindari. Globalisasi memiliki dampak positif ataupun negatif bagi dunia pendidikan termasuk pendidikan Islampersoalan pendidikan Islam di era modern ini semakin rumit, bahkan bisa dikatakan bahwa kualitas pendidikan mengalami penurunan yang bisa dilihat adalah pendidikan belum sepenuhnya mampu membentengi generasi muda dalam penguatan mental keberagamaan. Hal ini dikarenakan penerapan nilai ajaran Islam yang masih lemah. Menurut Ki Hajar Dewantara bahwa pendidikan di sekolah masih Tribakti: Jurnal Pemikiran Keislaman Volume 32, Nomor 1, Januari 2021 
menggunakan ujian di beberapa mata pelajaran untuk menilai potensi peserta didik. Belajar dinilai bukan lagi menjadi kebutuhan jiwa sebagai bekal dalam menjalani kehidupan, karena hanya nilai dan rangking yang dijadikan tujuan akhir belajar. Prestasi bukan untuk memenuhi kebutuhan namun hanya sebagai status. Fakta lain tentang sistem pengelolaan pendidikan di Indonesia juga masih menggunakan metode konvensional yang lebih memperhatiakan pengembangan kecerdasan semata tanpa memperhatikan kreativitas peserta didik. Banyaknya penyimpangan yang terjadi pada peserta didik seperti tawuran, dan pergaulan bebas merupakan bukti bahwa pendidikan Islam masih membutuhkan banyak pembenahan untuk mewujudkan tujuan pendidikan yang sesungguhnya. Upaya yang daat dilakukan pendidik dan praktisi pendidikan adalah melakukan pembaharuan untuk merekonstruksi dalam menyiakan masa depan.

Pendidikan adalah hal terpenting dalam kehidupan manusia dan juga membedakan manusia dengan makhluk lainnya. Pendidikan adalah proses menyiapkan penerus muda yang bisa menjalankan tujuan kehidupan dan memenuhi kebutuhan hidup di dunia secara efektif dan efisien. ${ }^{1}$ Pendidikan dalam Islam sebagai cara mewujudkan cita-cita hidup Islam untuk melestarikan dan mengirimkan nilai-nilai Islam pada kelompok penerusnya. ${ }^{2}$ Konsep pendidikan membutuhkan adanya perenungan yang sangat serius dan pemikiran yang bersifat ilmu yang bisa direalisasikan dengan mudah. Sebab tujuan akhir dari pendidikan Islam adalah untuk mengembangkan pemikiran manusia dan mengatur kehidupan berdasarkan tuntunan Islam dan bisa merealisasikan ubdiyah kepada Allah baik dikehidupan individu maupun bersama-sama. ${ }^{3}$ Pada arus globalisasi ini mewajibkan adanya cara dan strategi kependidikan agar bisa mengakomodasi perubahan di era global ini. Maka diperlukan seorang tokoh pembaharu yang benar-benar bisa menuangkan ide-ide dan gagasan yang bisa digunakan untuk menjadi pedoman ataupun menjadi acuan dalam mengajarkan pendidikan Islam, agar dalam dunia pendidikan tidak mandul dan bingung dalam menghadapi perubahan zaman yang makin berkembang.

Banyak sekali tokoh yang memiliki pemikiran pendidikan yang sangat berjasa dan menginspirasi untuk pendidikan Islam, seperti Abdurrahman Wahid dan Abdurrahman An-Nahlawi, Akankan di era globalisasi ini konsep pendidikan mereka masih cocok dan

\footnotetext{
1 Azyumardi Azra, Pendidikan Islam: Tradisi dan Modernisasi menuju Milenial Baru (Jakarta: Kalimah, 2001), 3.

${ }^{2}$ Abuddin Nata, Ilmu Pendidikan Islam (Jakarta: Kencana, 2010), 62.

3 Abdurrahman An-Nahlawi, Prinsip-Prinsip dan Metode Pendidikan Islam dalam Keluarga, di Sekolah dan Di Masyarakat (Bandung: Diponegoro, 1989), 162. 
bisa diaplikasikan dalam dunia pendidikan sekarang ini? Dikarenakan diera sekarang ini dibutuhkan metode dan strategi yang lebih bervariasi untuk mengatasi semakin berkembangan kemajuan zaman. Konsep pendidikan di era globalisasi membutuhkan metode dan strategi yang bervariasi sebagai pengembangan solusi untuk menjawab permasalahan pendidikan di era modern. Oleh karenanya dalam artikel jurnal ini akan membahas mengenai kesesuaian konsep pendidikan Islam menurut Abdurrahman Wahid dan Abdurrahman An-Nahlawi di era modern untuk menghadapi masa depan yang lebih baik.

\section{Metode}

Metode yang digunakan dalam penelitian ini adalah kepustakaan (library research) dengan menggunakan buku-buku dan literature-literatur lainnya sebagai sumber data yang utama. ${ }^{4}$ Pengumpulan data menggunakan pendekatan-pendekatan filosofis sosilogis yaitu menganalisis pemikiran seorang tokoh dan mengkaitkan dengan konteks sosial penulis dengan cara dokumentasi untuk memperoleh data dari naskah ataupun buku Abdurrahman Wahid dan Abdurrahman An-Nahlawi tentang pendidikan dan relevansinya dengan dunia modern. Adapun teknik analasis data menggunakan metode content analysis, ${ }^{5}$ yang membahas secara mendalam terhadap suatu informasi yang didapatkan dari media tertulis atau cetak dengan cara membandingkan isi dokumen satu dengan dokumen yang lainnya sehingga dapat ditarik kesimpulan. Dengan metode tersebut bisa diupayakan mampu menafsirkan isi dan juga ide-ide ataupun gagasan bagaimana relevansi pemikiran pendidikan menurut Abdurrahman Wahid dan Abdurrahman An-Nahlawi dengan dunia modern.

\section{Hasil dan Pembahasan}

\section{Pemikiran Abdurrahman Wahid dan Abdurrahman An-Nahlawi tentang Pendidikan}

\section{a. Pendidikan dan tujuannya}

Abdurrahman Wahid mengungkapkan bahwa modernisasi pendidikan Islam adalah salah satu pendekatan yang digunakan untuk menyelesaikan suatu persoalan umat Islam dimasa-masa yang akan datang, oleh karena itu modernisasi pendidikan suatu hal yang sangat penting dalam melahirkan suatu peradaban Islam yang modern yang bisa

\footnotetext{
${ }^{4}$ Sutrisno Hadi, Metodologi Research ( Yogyakarta: Andi Offset, 1990), 9.

${ }^{5}$ Cik Hasan Basri, Penuntun Susunan Rencana Penelitian dan Penulisan Skripsi Bidang Ilmu Agama Islam (Jakarta: Logos, 1998), 56.

Tribakti: Jurnal Pemikiran Keislaman

Volume 32, Nomor 1, Januari 2021
} 
sesuai dengan perkembangan zaman. Jadi menurutnya pendidikan Islam haruslah menyelaraskan sesuatu yang tradisional dan modern namun tidak melupakan ajaran Islam. ${ }^{6}$ Gus Dur berpandangan bahwasannya inti dari pendidikan Islam harus dapat meluruskan respon terhadap tantangan modernisasi itu tersebut, namun kesadaran akan hal itu justru belum ada dalam pendidikan Islam saat ini. Hal inilah yang sangat mengkhawatirkan banyak kalangan. Oleh karenanya Gus Dur menawarkan kensep tujuan pendidikan yaitu pendidikan Islam berbasis modernisasi yang mana harus bisa menyelaraskan nilai-nilai lama yang baik, namun harus tetep melihat kedepan mengadopsi pemikiran barat yang relevan dengan Islam sehingga melahirkan pandangan yng modernism untuk melihat pesan nilai Al-Qur'an dan sunnah.

Sedangkan Abdurrahman An-Nahlawi mendefinisikan bahwa pendidikan adalah proses yang mempunyai sasaran dan tujuan yang secara mutlak pendidikan hanya Allah sang Maha Pencipta yang memberi fitrah dan segala potensi oleh karena itu pendidikan harus mengikuti aturan yang sudah ada sebagaimana syara' dan Din Allah. ${ }^{7}$ Jadi pendidikan menurut Abdurrahman An-Nahlawi adalah proses yang harus dilakukan secara bertahap yang mempunyai sasaran dan tujuan yang hendak dicapai untuk bekal dan juga ilmu dalam menjalani kehidupan didunia sesuai dengan tuntunan agama Islam. Abdurrahman An-Nahlawi sendiri mengungkapkan bahwa tujuan pendidikan Islam adalah untuk melatih dan meningkatkan pikiran manusia dan menata kehidupan manusia serta perasaan manusia berdasarkan tuntunan Islam yang pada akhirnya bertujuan untuk melaksanakan dan melakukan ketaatan dan penghambaan kepada Allah semata, jadi tujuan pendidikan menekankan pada kepasrahan atau pengabdian seorang hamba kepada Allah yang menyatu dalam diri individu maupun sosial. ${ }^{8}$

\section{b. Asas-Asas Pendidikan Islam}

Abdurrahman An-Nahlawi membagi asas-asas pendidikan Islam menjadi tiga yaitu: pertama Asas-asas ideal yang menjelaskan pandangan Islam tentang manusia yang pada hakikatnya bersumber dari dua asal yaitu ashlul ba'id yang artinya penciptaan pertama yang berasal dari tanah yang kemudian disempurnakan oleh Allah dengan cara ditiupkannya ruh. Ashlul qorib yaitu kejadian yang berawal dari nutfah. Abdurrahman An-Nahlawi pada asas ini menjelaskan hakikatnya manusia merupakan makhluk

\footnotetext{
${ }^{6}$ Ninik Masruroh dan Umiarso, Modernisasi Pendidikan Islam, 9 (Yogyakarta: Ar-Ruzz Media, 2011), 107.

${ }^{7}$ An-Nahlawi, Prinsip-Prinsip....., 32-33.

${ }^{8}$ Moh. Roqib, Ilmu Pendidikan Islam: Pengembangan Pendidikan Integratif di Sekolah, Keluarga, dan Masyarakat (Yogyakarta: LKiS Yogyakarta, 2009), 27-29. 
istimewa yang dianugerahi Allah berupa akal pikiran yang dipakai untuk membedakan perkara yang baik dan yang buruk serta bisa dididik untuk mendapatkan ilmu pengetahuan. ${ }^{9}$

Pandangan Islam tentang alam tidak semata-mata rasional, dan itu merupakan cirri khas Islam. Seluruh alam adalah makhluk Allah yang harus tunduk kepada Allah sesuai dengan ketentuan-ketentuannya. Kehidupan berdasarkan sudut pandang Islam adalah ajang tempatnya mendapatkan kesulitan dan masalah dari Allah yang diberikan kepada manusia, sifat dunia yang tidak abadi dan sepintas gambaran kebahagiaan sementara yang digunakan untuk ladang manusia dalam menuju akhirat. Pemahaman mendalam terhadap kehidupan dunia yang digambarkan Allah secara menyeluruh, menyeru dan mendidik kaum muslimin untuk memiliki pertahanan yang kuat, seorang muslim harus dapat menghindari tipu daya dunia yang bisa melalaikan diri dari tujuan penciptaan manusia. ${ }^{10}$

Kedua yaitu asas Ta'abbudiyyah yang membahas mengenai ibadah. Pelaksanaan ibadah dalam Islam merupakan bentuk peraturan hidup seorang muslim berupa amal sholeh. Ibadah yang dimaksud An-Nahlawi adalah bentuk mempersatukan tujuan umat Islam untuk menanam hubungan dengan semua muslim, mendidik keutuhan umat muslim yang berserah diri kepada Allah. ${ }^{11}$ Asas ketiga yaitu asas tasyri'i. Syari'at Islam merupakan salah satu pendidikan Islam yang besar. Menurut makna Qur'ani, syari'at adalah penyempurna akidah, ibadah, mengatur kehidupan, serta batas dan pengatur semua hubungan insaniah. Berikut beberapa pengertian yang menyatakan kedudukan syari'at, yaitu syari'at adalah asas berfikir yang membahas tentang semua konsep berfikir yang berhubungan dengan kehidupan di dunia. Syari'at menetapkan kaidah dan tata sikap perbuatan muslim yang dijadikan contoh kehidupan sebagai teladan, keteraturan. Syari'at juga membutuhkan keahlian baca tulis, membaca al-Qur'an dan memikirkan hukum serta maknanya. ${ }^{12}$ Syari'at merupakan asas berpikir tentang kehiduan dunia, syari'at merupakan kaidah dan tata sikap perbuatan seorang muslim,dan syari'at merupakan keahlian baca tulis membaca al-qur'an beserta hukum-hukumnya.

\section{c. Pendidik dan Peserta didik}

Hakikat pendidik dalam Islam berdasarkan bukunya Abdurrahman An-Nahlawi adalah orang yang bertanggung jawab dalam tumbuh kembang sikap dan juga mental

\footnotetext{
${ }^{9}$ An-Nahlawi, Prinsip-Prinsip, 52-63.

${ }^{10}$ An-Nahlawi, 65-78.

${ }^{11}$ An-Nahlawi, 89-95.

${ }^{12}$ An-Nahlawi, 100-103.
}

Tribakti: Jurnal Pemikiran Keislaman

Volume 32, Nomor 1, Januari 2021 
peserta didik dengan mengerahkan semua potensi dan kemampuannya, baik potensi spiritual, efektif, kognitif maupun psikomotor menuju arah yang lebih baik dan seimbang dengan nilai Islam. ${ }^{13}$ Pendidik memiliki banyak fungsi dan peran yang sangat besar sebagaimana yang telah dibebankan Allah kepada Rasulullah dan pengikutnya, maka dari itu seorang pendidik harus memiliki sifat rabbaniyah dengan penuh keikhlasan, memiliki kesabaran dalam mengajarkan ilmunya, memiliki sifat jujur dalam kehidupan meningkatkan pengetahuan kreatif dan inovatif dalam menciptakan metode belajar memiliki sikap tegas, peka dan adil terhadap semua anak didiknya, mampu memahami psikologi anak, perkembangan dan juga psikologi pendidikan. ${ }^{14}$

Peserta didik adalah objek yang setiap saat guru dapat mengarahkan ataupun mengajarkan semua potensi dan juga ilmu pengetahuaannya dengan kesiapan peserta didik yang sudah benar-benar siap. Menurut pasal 1 ayat 4 UU RI No.20 Tahun 2003 tentang Sistem Pendidikan Nasional, peserta didik adalah anggota masyarakat yang berusaha mengembangkan dirinya melalui proses pendidikan pada jalur jenjang dan jenis penndidikan tertentu. Dengan demikian, peserta didik dalam Islam adalah anggota masyarakat yang berusaha untuk mencari ilmu, mengembangkan diri dan juga potensinya melalui proses pendidikan dengan tujuan untuk memperoleh ilmu pengetahuan, imantaqwa, akhlak dan juga bekal, sehingga mampu menjalakan fungsinya sebagai hamba yang hanya beribadah kepada Allah dan juga sebagai khalifah di dunia. ${ }^{15}$ Adapun etika peserta didik adalah selalu menyertai pendidiknya dan berusaha mengambil sesuatu yang bermanfaat, sopan, menghormati, mendengarkan nasihatnya, melembutkan suara dan tidak mendebat dengan kerah, selalu tekun dan serius mendengarkan penjelasan didalam proses pembelajaran. ${ }^{16}$

\section{d. Kurikulum pendidikan}

Kurikulum adalah hal pokok yang penting dalam bentuk dan rencana pendidikan proses pembelajaran tidak dapat berjalan lancar tanpa adanya kurikulum, sehingga pendidik harus dapat memahami kurikulum yang digunakan agar tujuan pembeljaran dapat tercapai. ${ }^{17}$ Gus Dur berpandangan bahwa kurikulum merupakan salah satu

13 Maragustam, Filsafat Pendidikan Islam: Menuju Pembentukan Karakter Menghadapi Arus Globalisasi, (Yogyakarta: Kurnia Kalam Semesta, 2016), 203.

${ }^{14}$ Maragustam, 170-175.

15 Maragustam, Filsafat Pendidikan Islam, 214-215.

16 Maragustam, Filsafat Pendidikan Islam Menuju Pembentukan Karakter (Yogyakarta: Pascasarjana FITK UIN Yogyakarta, 2018), 224.

${ }^{17}$ Toto Suharto, Filsafat Pendidikan Islam (Jogjakarta: Ar-Ruzz Media, 2013), 125. 
komponen penting dalam pendidikan karena kurikulum merupakan kerangka substansi pembelajaran yang berisi tujuan, materi, metode, dan lainnya. Gus Dur melihat pendidikan yang diterapkan bukan hanya materi-materi yang diajarkan, namun juga pada pola kehidupan yang sangat mendukung perkembangan peserta didik. Kurikulum pendidikan yang digunakan pada dasarnya adalah semua yang dipelajari di pondok pesantren yang mana nilai keIslaman ditularkan dari generas ke generasi. Gus Dur menjelaskan urgensi standarnisasi kurikulum pesantren, signifikansi perumusan modelmodel kurikulum pesantren, dan rumusan kurikulum pesantren, menggunakan istilah penyeregaman kurukulum. Pesantren sebagai lembaga pendidikan Islam, maka model kurikulum yang dipakai menjadi barometer kualitas pelaksanaan proses pendidikannya. ${ }^{18}$

Abdurrahman An-Nahlawi berpendapat bahwa kurikulum adalah cara atau tingkatan yang ada dalam pengajaran maupun lingkungan sekolah tertentu. Kurikulum digunakan sebagai acuan pembelajaran dalam membentuk dan mendidik akhlak peserta didik agar menjadi manusia yang bermanfaat.

Hal terpenting dalam kurikulum Islam menurut Abdurrahman An-Nahlawi dalam bukunya harus mencakup beberapa karakteristik, yaitu ${ }^{19}$ (a) harus memiliki system pengajaran dan juga materi yang sepadan dengan fitrah manusia. (b) bisa mencapai tujuan pendidikan Islam. (c) tingkatan dalam kurikulum Islam sesuai dengan tingkat pendidikan yang diterapkan. (e) Sistem kurikulum harus terbebas dari konstruksi. (f) Harus miliki metode yang elastic dan realistis sehingga dapan diadaptasi dan menyesuaikan dengan berbagai kondisi lingkungan maupun keadaan yang terjadi. (g) Harus efektif dan bisa menghasilkan pendidikan yang. (h) harus menyesuaikan tingkatan usia anak dan mempertimbangkan pendidikan dari segi perbuatan atau tingkah laku yang bersifat langsung.

\section{e. Metode Pendidikan}

Metode pendidikan Islam merupakan cara umum dalam mentransfer ilmu pengetahuan untuk mendapatkan tujuan pendidikan yang berdasarkan atas asumsi tertentu mengenai hakikat Islam sebagai kekuatan sistem. ${ }^{20}$ Metode mempunyai peran yang sangat penting dalam proses pembelajaran. Metode yang sesuai dan menarik dapat membantu pendidik dalam mencapai tujuan pembelajaran dengan mudah dan cepat. ${ }^{21}$

18 Abdurrahman Wahid, Standarisasi Sarana Ilmiah di Pondok Pesantren, (1978) dalam Bunga Rampai Pesantren, 147.

${ }^{19}$ An-Nahlawi, Pendidikan Islam di Rumah, 193-199.

${ }^{20}$ Moh. Roqib, Ilmu Pendidikan Islam, 91.

${ }^{21}$ Maragustam, Filsafat Pendidikan Islam, 223.

Tribakti: Jurnal Pemikiran Keislaman

Volume 32, Nomor 1, Januari 2021 
Metode pendidikan Islam sangat efektif untuk melatih kepribadian peserta didik dan memberikan pemahaman kepada peserta didikbahwa manusia adalah makhluk yang lemah dan fana. ${ }^{22}$

Metode pendidikan Gus Dur tidak memakai aturan-aturan yang baku, namun menggunakan metode yang sesuai dengan kondisi psikologi dan sosiologi peserta didik. Adapun metode-metode yang digunakan yaitu (a) metode qishas yaitu metode pendidikan dengan bercerita agar dapat diresapi dan diambil amanat dari suatu cerita, (b) metode ta'lim al-kitab yaitu pembelajaran melalui membaca maupun menerjemahkan, (c) metode ibrah atau mau'izah yaitu melalui pembelajaran untuk peringatan atau pelajaran. ${ }^{23}$ Sedangkan Abdurrahman An-Nahlawi mengemukakan beberapa metode pendidikan yang dapat diterapkan dalam pelaksanaan pendidikan Islam yaitu ${ }^{24}$ Metode pendidikan dengan hiwar (percakapan) qur'ani dan nabawi yaitu yang menggunakan kisah qur'ani dan nabawi, metode pendidikan dengan perumpamaan (amsal), dimana metodenya menggunakan contoh yang baik (uswah hasanah), metode pendidikan dengan latihan dan pengalaman, yaitu pendidikan dengan ibrah (pelajaran) dan mau'izah (peringatan), metode pendidikan dengan targhib (membuat senang) dan tarhib (membuat takut). Konsep metode yang digunakan Abdurrahman A-Nahlawi secara garis besar hamper sama dengan konsep pendidikan dari tokoh-tokoh lain.

\section{Relevansi Pemikiran Pendidikan Abdurrahman Wahid dan Abdurrahman An-}

\section{Nahlawi dengan Dunia Modern}

Perkembangan ilmu pengetahuan dan teknologi di era globalisasi memberikan dampak pada semua lapisan aspek masyarakat termasuk pendidikan. Upaya yang dapat dilakukan pemerintah Indonesia adalah meningkatkan mutu dan kualitas pendidikan dengan system pendidikan yang sesuai dengan standar mutu pendidikan di era global. Hal ini membutuhkan metode dan strategi yang tepat agar tujuan pembelajaran tercapai sesuai dengan yang diharapkan. Gus Dur memandang bahwa dampak pendidikan di Indonesia masih belum terlihat jelas. Pendidikan Islam di Sekolah mengajarkan pembelajaran yang dimasuki dengan nilai-nilai keIslaman yang berkaitan erat dengan kehidupan sehari-hari. Gus Dur dalam proses pembelajarannya menggunakan metode penalaran peserta didik untuk melatih peserta didik berpikir kritis. Adapun tujuan pendidikan menurut Gus Dur

\footnotetext{
${ }^{22}$ An-Nahlawi, Pendidikan Islam di Rumah, 204.

${ }^{23}$ Sri Minarti, Ilmu Pendidikan Islam, ( Jakarta: Amzan, 2013), 139.

${ }^{24}$ Toto Suharto, Filsafat Pendidikan Islam, 137.
} 
adalah memanusiakan manusia. Sehingga, pendidikan diharapkan dapat memberikan bekal manusia untuk bebas dalam mengembangkan fitrahnya kurikulum yang digunakan Gus Dur tidak hanya transfer of knowledge saja, tetapi juga transfer of value yang akhirnya membentuk karakter baik pada peserta didik. Dengan demikian, pendidikan Islam diharapkan dapat menjadi tumpuan untuk kemajuan bangsa guna menjadi sarana untuk memberikan pesan positif bagi kehidupan manusia.

Konsep pendidikan Abdurrahman An-Nahlawi menggunakan pendekatan psikologis untuk mendekati peserta didiknya guna mengetahui lebih dalam kendala dan masalah yang dihadapi peserta didik, sehingga [pendidik] bisa menyiapkan metode yang sesuai dengan kondisi peserta didik. Selain itu, An-Nahlawi memberikan metode-metode. yang menarik sebagai solusi dalam masalah pendidikan yang bersumber dari Al-Qur'an Pemilihan strategi dan metode dapat juga mengadopsi dari metode barat meskipun Islam mempunyai metode asli yang bersumberdari Alqu-an danmasih relevan untuk digunakan di era modern ini. Strategi dan metode yang digunakan harus disesuaikan dengan situasi dan kondisi psikologis maupun lingkungan peserta didik.

Menurut An-Nahlawi menjadi pendidik tidak cukup jika pintar secara akademik saja, tetapi juga harus bisa memahami dan peka terhadap peserta didik dan lingkungan sekitarnya. Pendidik juga harus memiliki kepribadian yang baik sehingga bisa menjadi suri tauladan yang baik untuk peserta didiknya. Maka dari itu, Pendidik saat ini dituntut untuk aktif dan paham mengenai perkembangan zaman untuk meningkatkan kualitas pendidikan. Kurikulum yang digunakan An-Nahlawi mengacu pada konsep Islam yang digunakan untuk mendidik bangsa yang berkarakter Islami dan berakhlakul karimah yang bersumber dari Al-Qur'an. Kurikulum yang digunakan saat ini belum tampak mengarah pada tujuan Islam sebagaimana tujuan pendidikan An-Nahlawi. Sistem pendidikan berdasarkan pemikiran An-Nahlawi adalah pembelajaran yang mengarahkan pada kesatuan Islam, sesuai dengan kemampuan psikologis yang telah Allah berikan serta sesuai dengan pengalaman peserta didik.

Tujuan pendidikan Islam menurut Abdurrahman An-Nahlawi adalah mengembangkan pola fikir manusia dan mengatur perilaku dan perbuatan serta perasaan mereka berdasarkan Islam yang bertujuan untuk melaksanakan ketaatan dan penghambaan kepada Allah di dalam kehidupan manusia baik individu maupun masyarakat. Tujuan tersebut memberikan pemahaman pada peserta didik bahwa apapun yang kita lakukan dan kerjakan pasti akan mendapat balasan sesuai dengan apa yang 
dilakukan. Jadi, pemikiran Abdurrahman An-Nahlawi tentang pendidikan masih sangat relevan sekali untuk diterapkan di era modern, menurut An-Nahlawi ada tiga factor yang dapat mempengaruhi perkembangan peserta didik. Pertama adalah keluarga, Keluarga mempunyai peran utama dalam mendidik anak terutama orang tua, karena orang tua akan menjadi teladan bagi anak-anaknya. Kedua adalah sekolah, sekolah juga mempunyai peran penting dalam pendidikan anak yang belum didapatkan anak di keluarganya. Pendidikan dikeluarga lebih mengarah pada pembentukan karakter, sedangkan pendidikan di sekolah untuk mengembangkan atau melanjutkan pendidikan anak dari rumah. Ketiga adalah lingkungan masyarakat. Lingkungan merupakan factor penting juga terhadap perkembangan anak. Usia anak sekolah merupakan usia pembelajar dimana secara psikologi masih bersifat labil, sehingga anak terengaruh oleh lingkungannya. Apabila pendidikan dasar anak tidak kuat maka anak mudah dipengaruhinya. Jadi, dapat disimpulkan bahwa konsep pendidikan berdasarkan pemikiran Abdurrahman an-Nahlawi masih relevan untuk diterapkan di zaman sekarang, karena teori-teorinya disesuaikan dengan pendekatan psikologi, yaitu memahami dan menyesuaikan situasi dan kondisi peserta didik.

Relevansi pemikiran pendidikan Islam Abdurrahman Wahid dan Abdurrahman AnNahlawi mempunyai kesamaan tujuan untuk memberikan pengalaman dan wawasan baru dengan mengedepankan peran aktif peserta didik dalam mengembangkan diri, untuk siap] menghadapi dan menyesuaikan setiap kondisi lingkungan masyarakat.

\section{Kesimpulan}

Pendidikan adalah suatu usaha yang lakukan oleh seseorang atau kelompok untuk bisa memperoleh hasil yang baik berdasarkan tujuan dan harapan untuk memahami dan mendapatkan tingkat kehidupan yang lebih baik dari segi mental. Konsep pendidikan berdasarkan pemikiran Abdurrahman Wahid dan Abdurahman an-Nahlawi masih sangat relevan untuk diterapkan saat ini karena teori dan metode yang digunakan dalam pendidikan Islam disesuaikan dengan perkembangan zaman yang menggunakan] pendekatan psikologi, dimana pembelajarannya sangat menghargai potensi peserta didik dan pendekatan tersebut dapat melatih daya nalar peserta didik. 


\section{Daftar Pustaka}

Abdullah M, Nur Muhammad. Studi Komparasi Konsep Pendidikan Islam dalam Keluarga Menurut Abdurrahman An-Nahlawi dan Abdullah Nashih 'ulwan. Yogyakarta: UIN Sunan Kalijaga. 2003.

An-Nahlawi, Abdurrahman. Prinsip-Prinsip dan Metode Pendidikan Islam dalam Keluarga, di Sekolah dan Di Masyarakat. Bandung: Diponegoro. 1989.

An-Nahlawi, Abdurrahman. Pendidikan Islam di Rumah Sekolah dan Masyarakat. Jakarta: Gema Insani. 1995.

Azra, Azyumardi. Pendidikan Islam: Tradisi dan Modernisasi menuju Milenial Baru. Jakarta: Kalimah. 2001.

Basri, Cik Hasan. Penuntun Susunan Rencana Penelitian dan Penulisan Skripsi Bidang Ilmu Agama Islam. Jakarta: Logos. 1998.

Hadi, Sutrisno. Metodologi Research. Yogyakarta: Andi Offset. 1990.

Istikhori. "Pemikiran Abd Al-Rahman Al-Nahlawi Tentang Pendidikan Masyarakat," Edukasi Islam Jurnal Pendidikan. Vol.06 No.12, Juli. 2017.

Maragustam. Filsafat Pendidikan Islam: Menuju Pembentukan Karakter Menghadapi Arus Globalisasi. Yogyakarta: Kurnia Kalam Semesta. 2016.

Maragustam. Filsafat Pendidikan Islam Menuju Pembentukan Karakter. Yogyakarta: Pascasarjana FITK UIN Yogyakarta. 2018.

Masruroh, Ninik dan Umiarso. Modernisasi Pendidikan Islam, 9. Yogyakarta: Ar-Ruzz Media. 2011.

Moh. Roqib. Ilmu Pendidikan Islam: Pengembangan Pendidikan Integratif di Sekolah, Keluarga, dan Masyarakat. Yogyakarta: LKiS Yogyakarta. 2009.

Nata, Abuddin. Ilmu Pendidikan Islam. Jakarta: Kencana. 2010.

Nata, Abudin. Tokoh-tokoh Pembaharuan Pendidikan Islam di Indonesia. Jakarta: Raja Grafindo Persada. 2005.

Suharto, Toto. Filsafat Pendidikan Islam. Jogjakarta: Ar-Ruzz Media. 2013.

Sutrisno dan Suyatno. Pendidikan Islam di Era Peradaban Modern. Jakarta: Prenadamedia Group. 2015. 


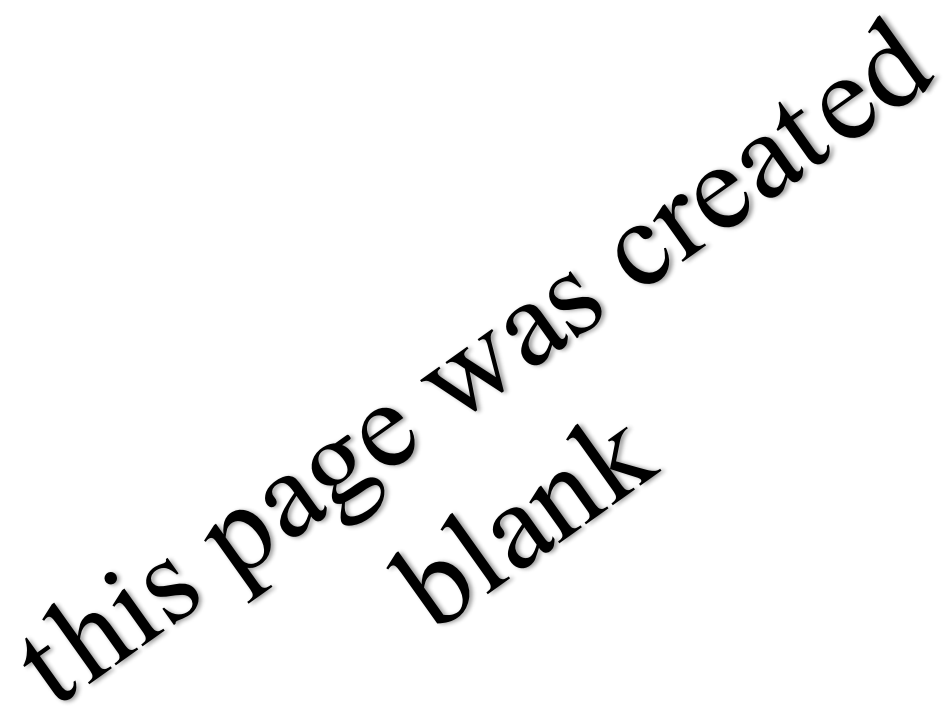

